\title{
Function and regulation of the Arabidopsis floral homeotic gene PISTILLATA
}

\author{
Koji Goto ${ }^{1}$ and Elliot M. Meyerowitz ${ }^{2}$ \\ Division of Biology 156-29, California Institute of Technology, Pasadena, California 91125 USA
}

\begin{abstract}
Mutations in the PISTILLATA (PI) gene of Arabidopsis thaliana cause homeotic conversion of petals to sepals and of stamens to carpels. It is thus classed as a B function floral homeotic gene and acts together with the product of the other known B function gene, APETALA3 (AP3). We have cloned PI and determined the time and places of its expression in developing flowers. Surprisingly, the initial patterns of $P I$ and $A P 3$ expression are different. By positive regulatory interactions between $P I$ and $A P 3$, later expression patterns are coincident or nearly coincident. The pattern of $P I$ expression also depends on the activity of the floral development genes APETALA2 and SUPERMAN and on the activity of PI itself. The PI and APETALA3 proteins specifically associate in solution and so may act together in regulating $P I$ and other genes.
\end{abstract}

[Key Words: Flower development; Arabidopsis; homeosis; MADS box; gene regulation]

Received March 8, 1994; revised version accepted May 12, 1994.

A model explaining how the action of a collection of organ identity (homeotic) genes specifies the radial pattern of the four organ types of Arabidopsis flowers has been proposed and elaborated over the past few years (Bowman et al. 1991; Coen and Meyerowitz 1991; Drews et al. 1991b; Meyerowitz et al. 1991; Jack et al. 1992, 1994; Weigel et al. 1992). This model includes three classes of organ identity genes: class A genes that act in the regions of developing flowers that will later form sepals and petals (whorls 1 and 2); class B genes that act in whorls 2 and 3 (which later will be the site of petals and stamens, respectively); and class $C$ genes that act in the center of the flower, where the stamens and the ovary will develop (whorls 3 and 4). The overlapping pattern of activity of these three classes of genes defines four different regions (whorls) and specifies the four different types of floral organs. The class A genes that are presently known are APETALA2 (AP2) and APETALA1 \{AP1) (Bowman et al. 1989, 1993; Kunst et al. 1989; Meyerowitz et al. 1989, 1991; Irish and Sussex 1991; Mandel et al. 1992; Okamuro et al. 1993; Gustafson-Brown et al. 1994), the class B genes of Arabidopsis are PISTILLATA (PI) and APETALA3 (AP3) (Bowman et al. 1989, 1991; Meyerowitz et al. 1989, 1991; Jack et al. 1992), and the only known class C gene is AGAMOUS (AG; Bowman et al. 1989; Yanofsky et al. 1990; Drews et al. 1991a). To date, the molecular cloning of $A G, A P 3$, and $A P 1$ has been reported (Yanofsky et al. 1990; Jack et al. 1992;

\footnotetext{
${ }^{1}$ Present address: Molecular Genetics Research Laboratory, University of Tokyo, Bunkyo-ku Tokyo 113, Japan.

${ }^{2}$ Corresponding author.
}

Mandel et al. 1992). This report describes the molecular cloning, sequence analysis, coding properties, and regulation of expression of $P I$.

Plants lacking $P I$ function have sepals in the places where petals would be found in wild-type flowers and have carpels, filaments, or carpelloid organs in the positions normally occupied by stamens (Bowman et al. 1989, 1991; Hill and Lord 1989). PI is therefore necessary for the proper specification of organ identity in the second and third whorls in developing Arabidopsis flowers. The other gene in the $\mathrm{B}$ class, $A P 3$, has an indistinguishable mutant phenotype (Bowman et al. 1989, 1991; Jack et al. 1992). Activity of both of these genes is thus required for specification of petal and stamen organ identity. The molecular cloning of $A P 3$ has shown it to be a member of the MADS box family of DNA-binding transcription factors (Jack et al. 1992). AP3 RNA is found in the cells of the second and third whorls in developing flowers.

There is a series of open questions concerning the activity of $P I$. Is $P I$ a transcription factor, and a member of the MADS box family, similar to $A P 3, A G$, and $A P 1$ ? What is the expression domain of $P I$ ? Is it restricted to whorls 2 and 3 , like $A P 3$, or is it expressed in a broader domain and restricted in its activity by the limited expression of $A P 3$ ? What is the basis of the similarity of the $A P 3$ and $P I$ mutant phenotypes? Do the proteins coded by these genes act as a heteromultimer, thus causing the mutations to give identical developmental defects, or do the genes act as positive regulators of each other? There are open evolutionary questions, as well. The cognate homolog (ortholog) of AP3 in snapdragons (Antirrhinum 
majus) is the related gene DEFICIENS (DEF). DEF acts in partnership with the other known B class gene in snapdragons, GLOBOSA (GLO; Tröbner et al. 1992). Is PI the Arabidopsis ortholog of GLO?

In this paper we describe experiments that have answered these questions. PI is a member of the MADS box family but initially expressed in a different domain than $A P 3$. The later expression patterns of $P I$ and $A P 3$ are much more similar; this appears to be attributable to a refinement of the $P I$ expression pattern that occurs, at least in part, under the control of $A P 3$. Both possibilities for the interaction of $A P 3$ and $P I$ are true: Not only do the genes act as positive regulators of each other, but the proteins they encode associate to form heteromultimers in solution and thus may act together in regulating transcription. Sequence, phenotypic, and expression data make it seem likely that $P I$ is the cognate homolog of the snapdragon gene GLO.

\section{Results}

The PI gene and its product

Parallel attempts to clone PI were made by chromosome walking and by cross-hybridization, based on the assumption that PI is a member of the MADS box gene family. The second strategy was the first to yield the gene. The first step in cloning PI by MADS box homology was to locate the gene on the Arabidopsis restriction fragment length polymorphism (RFLP) map. Standard mapping identified the nearest flanking RFLP markers as g4650 and g6843 (Nam et al. 1989). Then, a variety of MADS box-containing sequences from Arabidopsis and Antirrhinum were used to isolate Arabidopsis genomic and cDNA clones. The resulting genomic clones were placed on the RFLP map to see whether any corresponded to the PI locus.

The successful probe was derived from the Antirrhi. num GLO gene (Tröbner et al, 1992). GLO cDNA was amplified by polymerase chain reaction (PCR) from $A$. majus flower RNA with degenerate oligonucleotides that were based on the derived amino acid sequence of GLO (Tröbner et al. 1992; see Materials and methods). The amplified GLO cDNA was used as a probe to screen an Arabidopsis flower cDNA library under reduced stringency conditions. From $2 \times 10^{4} \mathrm{cDNA}$ library plaques, eight strongly hybridizing clones were obtained. They have inserts of varying size, but DNA sequencing showed that all of them derive from the same RNA species. The longest clone (cGH12) has an insert of $916 \mathrm{bp}$ and includes a single long open reading frame of $624 \mathrm{bp}$ with a poly(A) tail.

Similar reduced-stringency screening of an Arabidopsis genomic cosmid library gave four clones, only one of which (GH13) hybridized strongly with the cDNA clones. This genomic clone was genetically mapped using RFLPs and found to represent a region very near the $P I$ locus. This result suggested that the cDNA clones represent the PI gene. Comparison of the cDNA and genomic clone sequences shows that the cloned gene has six exons and five introns (Fig. 1A). The introns are 997, $119,72,88$, and 102 bases in length, respectively.

To demonstrate that the cloned gene is $P I$, we sequenced three PI mutant alleles, pi-1, pi-2, and pi-3 (Bowman et al. 1991). In each, there is a DNA sequence alteration relative to the wild-type progenitor, and the nature of the changes correlates with the severity of the mutant phenotype (Fig. 1A; Bowman et al. 1991).

The PI cDNA has an open reading frame that codes for a putative 208 -amino-acid protein (Fig. 1B). This protein contains an amino-terminal MADS domain, the conserved DNA-binding domain also found in the Arabidopsis organ and meristem identity genes AGAMOUS, AP. ETALA3, and APETALA1, as well as in the Antirrhinum floral development genes DEF, GLO, SQUAMOSA, and $P L E N A$, and many additional florally expressed genes (Schwarz-Sommer et al. 1990; Sommer et al. 1990; Yanofsky et al. 1990; Ma et al. 1991; Pnueli et al. 1991; Angenent et al. 1992; Jack et al. 1992; Mandel et al. 1992; Tröbner et al. 1992). MADS box genes in other kingdoms include human serum response factor and yeast MCM1 (Norman et al. 1988; Passmore et al. 1988). In addition to the MADS box, the PI gene has a $\mathrm{K}$ box in the central part of the putative protein-coding region. The $\mathrm{K}$ box codes for a protein domain that resembles the amphipathic $\alpha$-helical region of keratin proteins that is responsible for coiled-coil formation (Ma et al. 1991; Pnueli et al. 1991). It is found in all of the sequenced plant MADS box genes but not in any of the MADS box genes from animals or fungi. Although there is structural conservation of the predicted amphipathic $\alpha$-helices coded by the $\mathrm{K}$ box in the various plant MADS box genes, there is generally very little amino acid sequence conservation in this region (Ma et al. 1991). Figure 2 shows a best-fit alignment of the MADS box genes most closely related to $P I$. The closest relatives are Antirrhinum and tobacco GLO and Petunia FBP1 and pMADS2. On the basis of its sequence, FBP1 is thought to be the Petunia ortholog of GLO (Angenent et al. 1992); pMADS2 is also thought to be a Petunia B function gene (van der Krol et al. 1993). PI, GLO, tobacco GLO, pMADS2, and FBP1, but not other MADS box proteins, are similar in parts of the proteins other than the MADS and K boxes. Met- 67 through Ile-113 in PI is identical in 37 of 47 amino acids to the comparable region in GLO, and 9 of the 10 replacements in this region are conservative. The carboxy-terminal ends of these proteins also show a region of near identity: amino acids 187-202 of PI and the corresponding terminal 16 amino acids of the other genes are identical in 10 positions. Overall, PI and GLO share $58.4 \%$ identity among the 202 amino acids paired in a best-fit alignment. This is close to the overall degree of identity shared by AP3 and DEF $(61.2 \%)$, and much more than that shown by the paralogous pairs PI-DEF $(29.8 \%)$ or AP3-GLO (33.0\%).

\section{Expression of PI during wild-type flower development}

A PI probe detects a 900- to 1000-base RNA transcript in RNA blots of floral RNA; it detects nothing when the 
Figure 1. Genomic structure and sequence of $P I$. $(A)$ (Top) The PI gene. The hatched boxes show exons; open boxes are the $5^{\prime}$ - and $3^{\prime}$-untranslated regions. ATG and STOP represent the initiation and stop codons, respectively. The length of the introns are, in order, 997, 119, 72, 88, and $102 \mathrm{bp}$. Arrows show the changes from wild type in the three pi mutant alleles. (Bottom) The PI cDNA, with the MADS box, the $\mathrm{K}$ box, and the position of the $3^{\prime}$ terminus of the open reading frame indicated. $(B)$ Nucleotide sequence of the longest $P I$ cDNA, and the amino acid sequence of the putative PI protein. The MADS box and $\mathrm{K}$ box are indicated with thick and thin underlining, respectively. Arrowheads show the intron boundaries. The amino acids thought to be altered by the three sequenced pi mutations are underlined. The stop codon is marked with an asterisk and (A)n shows the location of the poly|A t tail. Numbering begins with the first base of the longest cDNA clone as 1 ; The actual site of transcription initiation is not known.
A

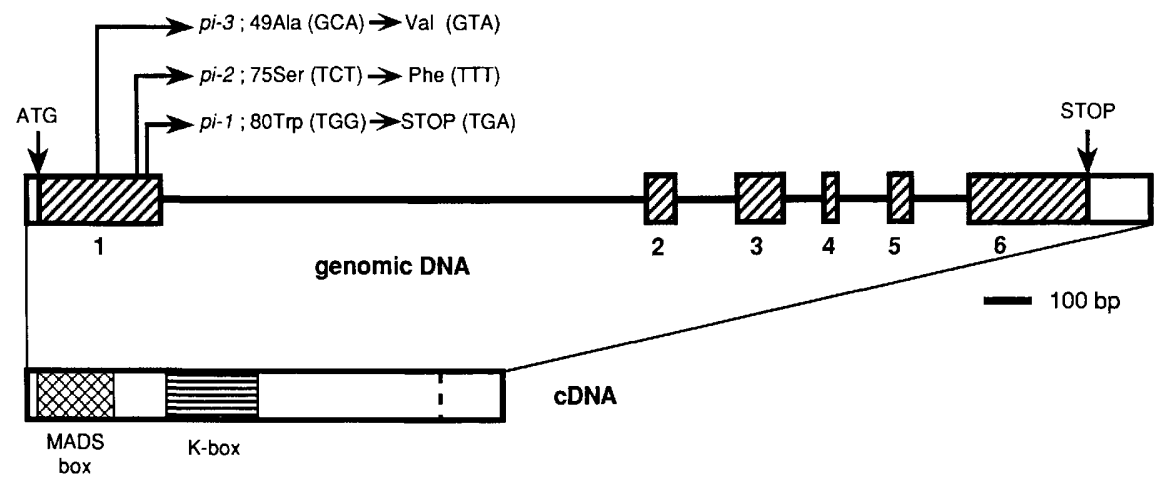

B

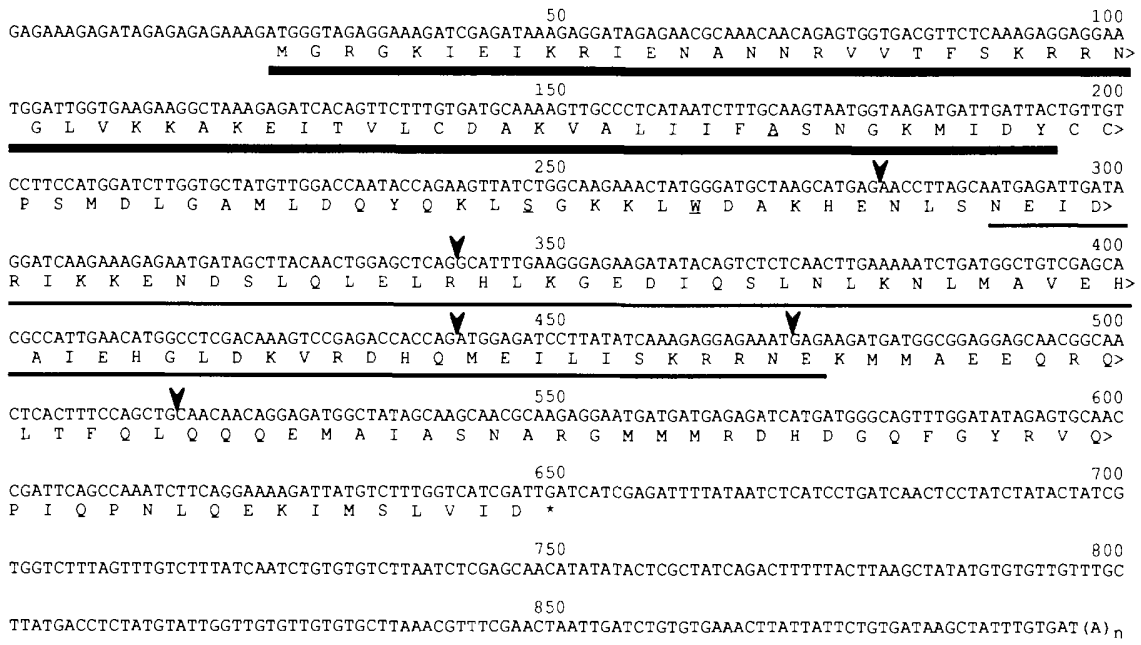

RNA is from vegetative tissues (data not shown). The frequency of obtaining PI cDNA clones from a floral cDNA library $\left(4 \times 10^{-4}\right)$ suggests that $P I$ does not code for a particularly rare RNA. To find the precise spatial and temporal expression pattern of the PI RNA, in situ hybridization was performed. The probe used was a ${ }^{35} \mathrm{~S}$ labeled antisense transcript from a PI cDNA clone, from which the sequences coding for the MADS box and the poly(A) tail had been removed, to prevent cross-hybridization to the RNA products of other MADS box genes. This probe, when used in genomic DNA blots under conditions of low stringency, shows only those restriction fragments that derive from the PI gene. Autoradiographic signal from the hybridized RNA is first seen in stage 3 flowers (Figs. $3 \mathrm{~A}$ and 4), the same stage when $A G$ and AP3 RNAs are first detected (Drews et al. 1991a; Jack et al. 1992; stages as defined in Smyth et al. 1990). In stage 3 , the cells that have accumulated detectable levels of PI RNA are all of those located centripetally to the early sepal primordia, including the central region of the floral meristem-that is, those cells that will later contribute not only to the formation of petal and stamen primordia but also those that will later form the ovary. This is an unexpected pattern, because the phenotypic effects of pi mutants are confined to the organs of the second and third floral whorls, whereas the early PI ex- pression domain includes not only the second and third whorls but also the fourth whorl. PI RNA gradually disappears from the fourth whorl cells; even in stage 3 the RNA appears to be at lower levels in whorl 4 than in whorls 2 and 3 , by stage 4 it is clearly at a lower level, and by stage 5 the PI RNA is not detected in the whorl 4 region of the developing flower (Figs. 3B, 4, and 5). PI RNA remains present at high levels in the developing second and third whorls, including the petals and stamens after they have formed, until well after the differentiation of the cells in each organ type /stages 10 and 11, Fig. 3C).

That this pattern of expression is truly different from that of the AP3 RNA was shown by direct comparison of similarly staged developing flowers hybridized with $P I$ or AP3 probes in in situ hybridization experiments (Fig. 4). Even at the earliest stages of expression, stage 3, AP3 RNA is not detected in the center of developing flowers, in a core of cells that is visible in a minimum of two adjacent $8-\mu \mathrm{m}$ sections (Fig. 4A,C,E). Comparable sections hybridized with $P I$ probe show signal throughout the central flower region, though there is a suggestion that the level of PI RNA may be lower in the center and increase toward the periphery of the flower (Fig. 4B,D,F). To demonstrate further that the $P I$ and $A P 3$ expression patterns are not identical, histological sections of devel- 

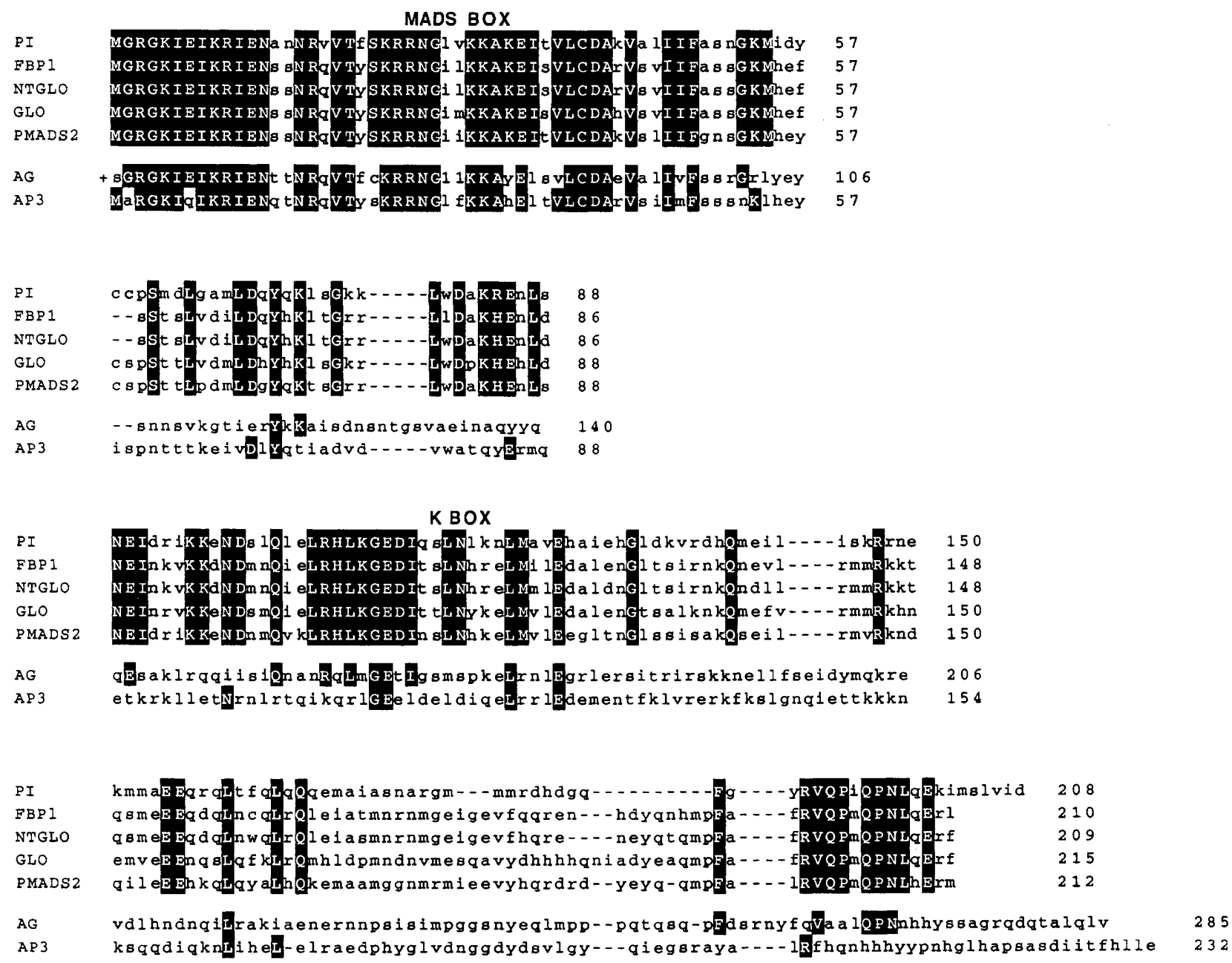

Figure 2. Best-fit alignment of the deduced sequence of the PI protein with some of the related deduced protein sequences from Arabidopsis and other species. PI, FBP1 (Angenent et al. 1992), NTGLO (Hansen et al. 1993), GLO (Tröbner et al. 1992), and PMADS2 (Kush et al. 1993) form the most closely related group. The uppercase amino acids in the sequences of these five are those shared by all five proteins. These genes are from Arabidopsis, Petunia, tobacco, Antirrhinum, and Petunia, respectively. Beneath them is shown the alignment of two Arabidopsis MADS box proteins (AG, Yanofsky et al. 1990; AP3, Jack et al. 1992), less closely related to PI than are any of the genes shown from the other species. The uppercase amino acids in these two sequences are those that are identical to the conserved amino acids in the proteins grouped with PI. The + at the amino-terminal end of AG indicates that this protein extends amino-terminally of the depicted portion. Dashes are gaps introduced to maintain alignment. The amino acid sequence alignment was done as described in Fryxell and Meyerowitz (1991).

oping inflorescences were made, and alternate sections were hybridized with $A P 3$ and $P I$ antisense probes. The thickness of the sections $(6 \mu \mathrm{m})$ is approximately a single cell width. These sections (Fig. 5) show that $A P 3$ is not expressed in the central floral cells at a time when $P I$ is expressed in them. This experiment was performed three times, with the same results each time. These experiments also suggest a possibility that the outer boundary of AP3 and PI expression is not identical, but without applying double-labeling methods with single-cell resolution, this possibility cannot be proven.

\section{Expression of PI in homeotic flower mutants}

One key question to be answered is the identity of the genes that specify the normal domain and timing of $P I$ expression, particularly the genes responsible for the restriction of $P I$ expression that occurs between stages 3 and 5. From their morphological effects, there are several floral development genes that could plausibly be regulators of $P I$, either directly or through their action on other genes. One candidate is AP3. The phenotypic effects of ap3 mutations are nearly identical to the effects of mutations in PI (Bowman et al. 1989, 1991; Jack et al. 1992). This could be because both genes contribute together to a common organ specification function or because one is a positive regulator of the other, with the downstream gene acting more directly in organ specification. We know that $P I$ function is not necessary for the appropriate initial (stages 3-5) pattern of $A P 3$ expression, because the early pattern of $A P 3$ RNA expression is normal in $p i$ mutants (Jack et al. 1992). To determine whether AP3 is 

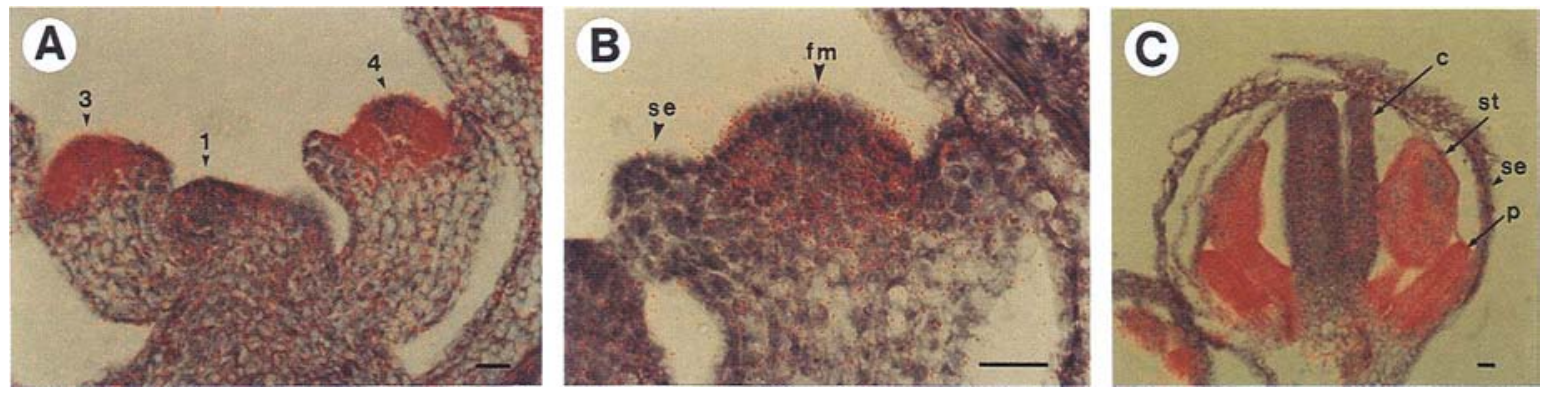

Figure 3. Expression of PI RNA in wild-type flowers. The distribution of PI RNA was determined by in situ hybridization to longitudinal 8 - $\mu$-thick tissue sections. The tissue was stained with toluidine blue (see Materials and methods). All photographs are bright-field/dark-field double exposures in which a red filter was placed in the light path of the microscope during the dark-field exposure, to cause the silver grains (signal) to appear red. Bars, $20 \mu \mathrm{m}$. (A) Inflorescence apex. In the inflorescence meristem and in floral meristems to stage 2, signal from the PI RNA is not seen above background levels. In early stage 3 flowers, $P I$ transcripts are first detectable in the cells that will later form the primordia of petals, stamens, and carpels but not in the cells that will develop to sepals. The developmental stage of each floral meristem (using the stages of Smyth et al. 1990) is indicated. (B) Higher magnification of a later stage 4 flower. At this stage, sepal primordia are apparent (se), but other organ primordia are not yet morphologically distinguishable from the remaining floral meristem $(\mathrm{fm})$. PI RNA is disappearing from the region that later will develop into carpels and is expressed in the cells between the sepal primordia and the outer boundary of the region that will develop into carpels. $(C)$ A stage 10 flower, when all floral organs are differentiating. PI transcripts are expressed at high levels throughout the stamens (st) and petals (p) but not in the carpels $(\mathrm{c})$ or sepals (se).

a positive regulator of $P I$ expression, we analyzed the pattern of expression of PI RNA in ap3-3 mutant flowers. This ap 3 mutant allele causes a severe mutant phenotype; the mutation is a change of the codon for the eighteenth amino acid in the deduced AP3 protein to a stop codon. The initial pattern of PI expression is normal in ap3-3 flowers; thus, for their initial expression patterns, $A P 3$ and $P I$ are independent (Fig. 6A). This is not true for later expression; high levels of PI RNA are not maintained after stage 4 or 5 in ap3-3 flowers (Fig. 6A). This indicates a role for $A P 3$ in maintenance, but not establishment, of $P I$ expression. Absence of $A P 3$ in the fourth whorl of wild-type flowers can therefore explain the disappearance of PI RNA from that region.

$P I$ is necessary for maintaining its own expression. In pi-1 mutant flowers, PI RNA accumulates normally in stages 3-6, before the primordia of the second and third whorl organs begin to differentiate obviously. Subsequently, the level of PI RNA decreases: The PI transcript is not detectable above background in flowers older than stage 7 (Fig. 6B). The weaker mutant allele pi-2 has a less severe effect on the reduction of PI RNA level. In pi-2 mutants PI RNA accumulates normally in early stages and is reduced to a level lower than normal in later stages, as is true in pi-1. In pi-2, however, $P I$ expression becomes reduced later than in pi-1 flowers, and the $P I$ RNA is present in fully developed flowers, although only at the base of the giant ovary in the region formed from the third whorl (Fig. 6C). In flowers homozygous for pi-3, the weakest allele, PI expression is similar to that in wild-type flowers (Fig. 6D). These results show that different gene products are responsible for the initial expression of $P I$ and for maintenance of that expression: Both $A P 3$ and $P I$ are involved in the maintenance of $P I$ expression, whereas neither is required for the initiation of $P I$ expression.

Another mutation that affects the PI expression pattern is superman. The phenotype of this mutation is reduction or elimination of the ovary, with concomitant formation of many extra stamens in the central region of each flower (Schultz and Haughn 1991; Bowman et al. 1992). One explanation for this mutant phenotype is that the absence of $S U P$ activity results in the expansion of the normal domain of $A P 3$ and PI function to include cells that would ordinarily develop into fourth-whorl carpels. That SUP normally acts as a repressor of $A P 3$

Figure 4. Serial sections through early-stage developing wild-type flowers, showing the different patterns of expression of $P I$ and $A P 3$. In situ hybridization to PI RNA in $8-\mu \mathrm{m}$ sections was used to show the position of PI RNA. Photographs were as described in the legend to Fig. 3, except a yellow filter was used in the dark-field exposure when the probe was to AP3 RNA, and a red filter for PI RNA. The rows of photographs labeled $A, C$, and $E$, with the autoradiographic silver grains colored yellow, are hybridized with an antisense $A P 3$ probe; the photographs in rows $B, D$, and $F$, color-coded red, show the hybridization pattern of an antisense $P I$ probe. The flowers shown in rows $A$ and $B$ are early stage 3; $C$ and $D$ are later stage 3 ; and rows $E$ and $F$ depict stage 4 flowers. In row $E$ one section has not been shown in the serial series; it comes between the third and fourth panel, and resembles the third panel. At stages 3 and 4 , at least two adjacent sections show undetectable levels of $A P 3$ RNA in the center of the developing flowers. There are no sections in which PI RNA is undetectable in the whorl four region of stage 3 and 4 flowers. It does appear that by stage 4 , the level of $P I$ RNA is declining in the center of the flowers. By late stage 4 or stage 5, PI RNA is undetectable in the whorl 4 region, and the PI expression pattern is indistinguishable from the AP3 pattern in the center of developing flowers (see Figs. 3 and 5). All panels are at the same magnification. The white size bar (bottom right) represents $50 \mu \mathrm{m}$. 

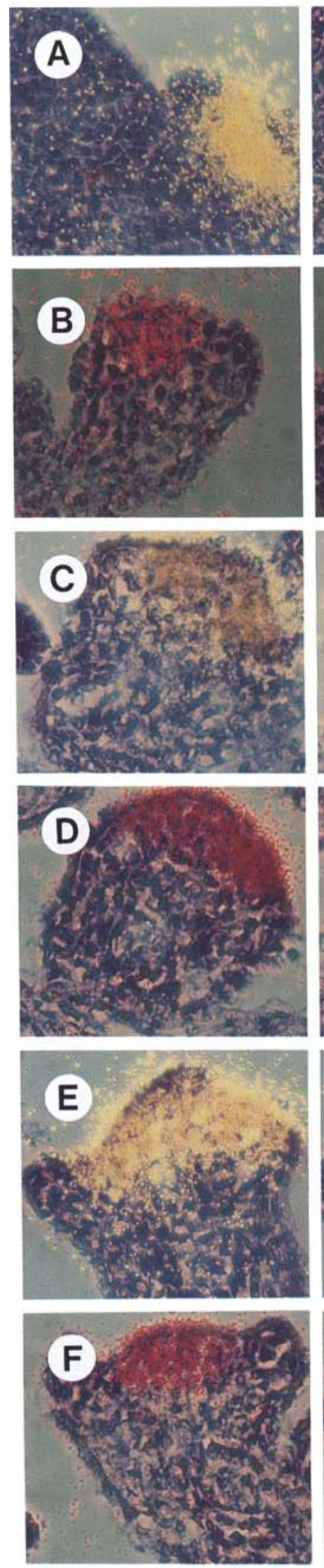
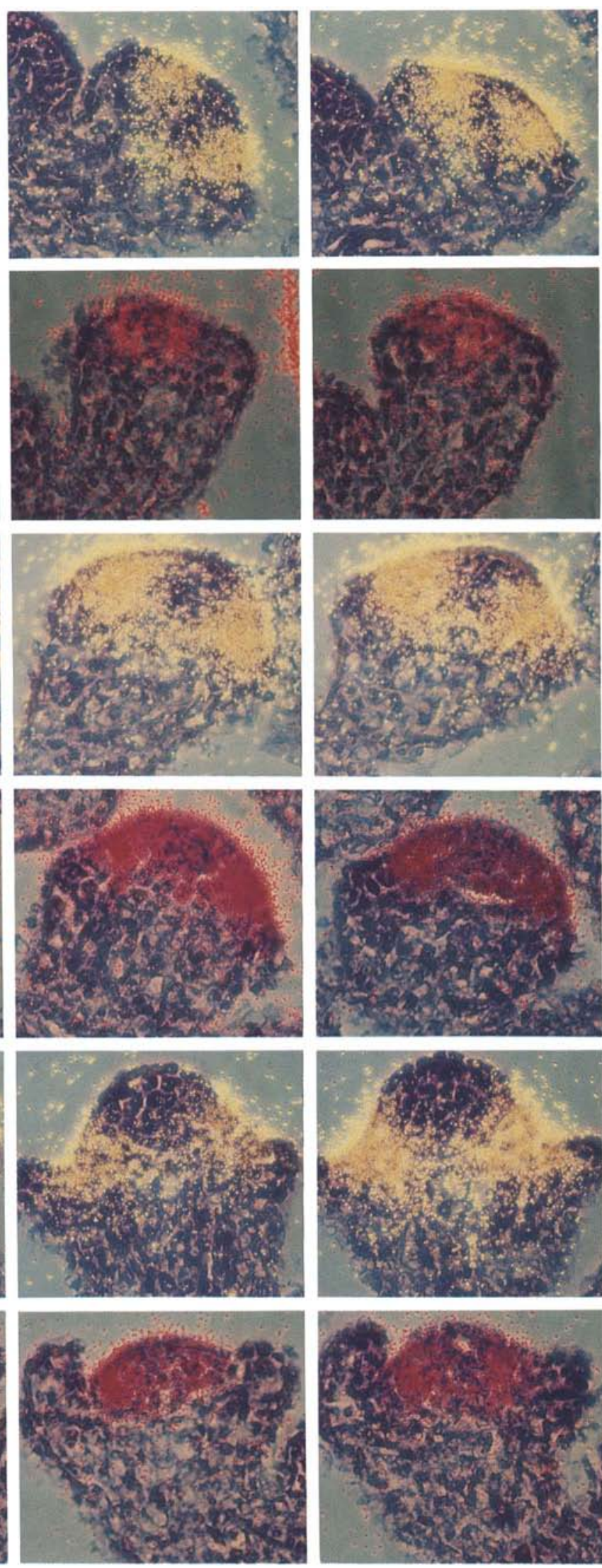
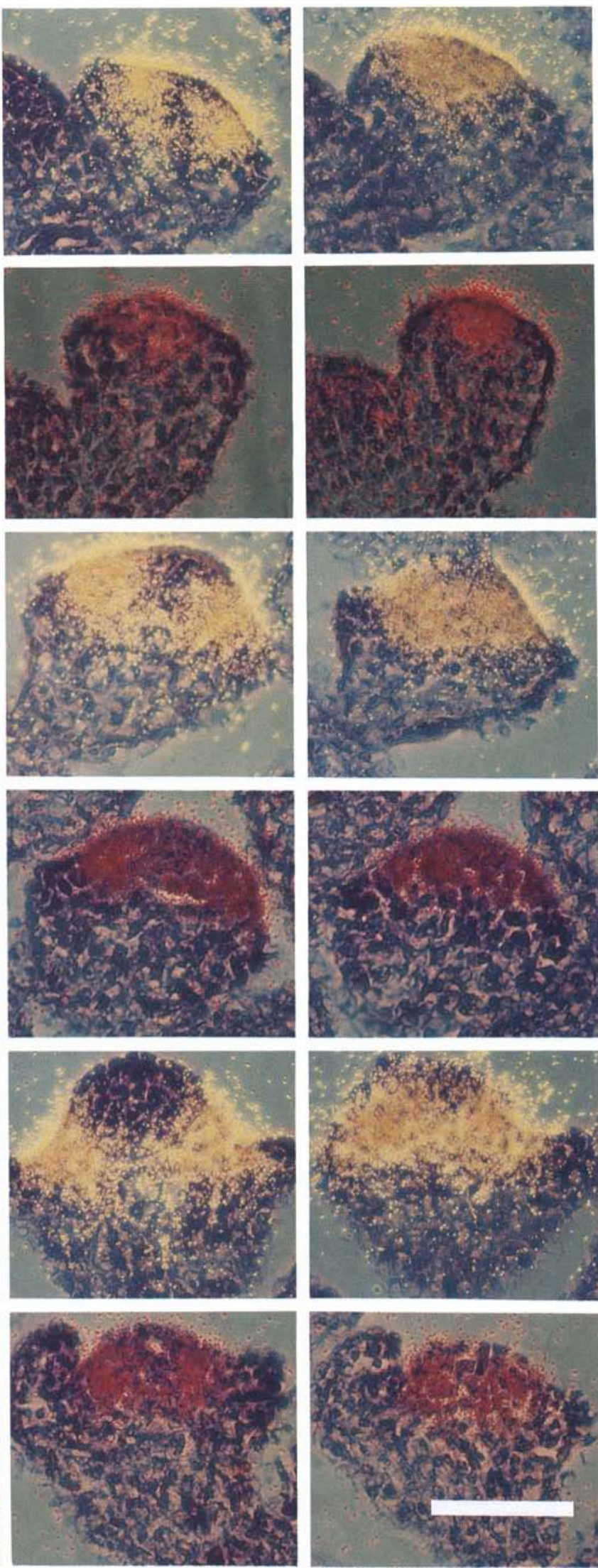

Figure 4. (See facing page for legend.) 
Figure 5. $P I$ and $A P 3$ expression in alternate sections of the same wild-type inflorescence. Adjacent $6-\mu \mathrm{m}$ sections of a wildtype inflorescence were alternately in situ hybridized with labeled antisense $P I(A, C)$ or $A P 3(B, D)$ probe. $\{A-D\}$ The serial order of the sections. The photographs are double exposures as in Figs. 3 and 4 ; in $A$ and $C$ a red filter was used during the dark-field exposure; while in $B$ and $D$ a yellow filter was used. Stage 3 (center), stage 6 (right), and stage 8 (left) flowers are shown in these photographs. Both $P I$ and $A P 3$ express in petals (p) and stamens (st), and not in sepals (se) or carpels $(\mathrm{c})$ when these organs are differentiating. In the stage 3 flower, $P I$ is expressed in the center, whereas AP3 is not. Bar, 50 $\mu \mathrm{m}$.
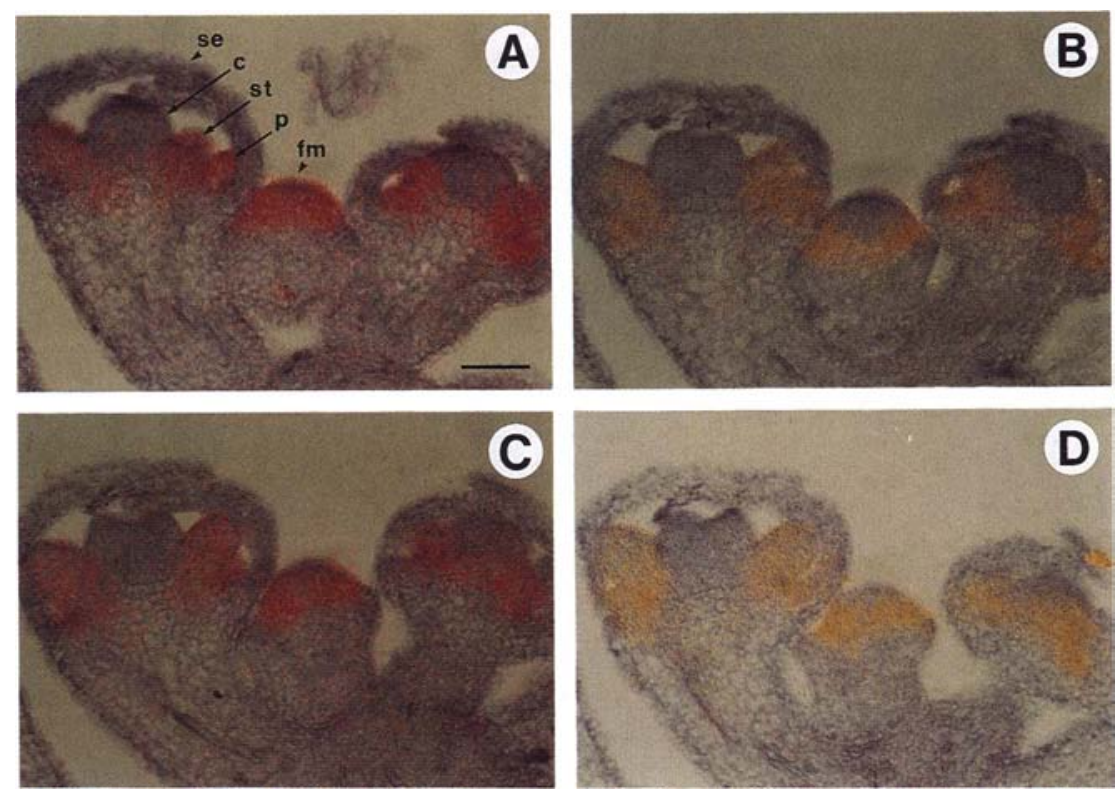

RNA accumulation in the fourth whorl has been shown directly by in situ hybridization with $A P 3$ antisense probes and sup homozygous flowers (Bowman et al. 1992). Parallel experiments with PI antisense probes were performed and show that the initial domain of $P I$ RNA accumulation in sup-1 mutant flowers is the whorl 2,3 , and 4 region of PI RNA accumulation in wild-type flowers. Later (after approximately stage 5) PI RNA is seen much more centrally than in wild type: Whorl 4 expression does not become reduced as in wild-type. In the center of the flowers, however, there is a small region free of $P I$ signal (Fig. 6E). The same lack of signal in a few central cells has been seen in similar experiments performed with an AP3 probe (Bowman et al. 1992; T. Jack and E.M. Meyerowitz, unpubl.). Formally SUP can be considered a negative regulator of both $P I$ and $A P 3$ in whorl 4. The direct effect of SUP may be only on AP3, however; and because $A P 3$ is a maintenance factor for $P I$, the absence of $S U P$ activity may indirectly allow continued expression of $P I$ in the center of developing flowers.

$A P 2$ is another candidate for a gene that controls $P I$ expression, because ap2 mutations are known to affect AP3 RNA levels: When strong ap2 alleles such as ap2-2 and ap2-8 are homozygous, AP3 RNA initially accumulates only to very low levels and in spatial domains smaller than in wild type. PI RNA expression resembles that of AP3 in ap2-8 homozygotes (Fig. 6F,G). The expression pattern of PI RNA has been examined in two additional mutant genotypes, ag-1 and ap1-1. PI expression is as expected if the $A G$ and $A P 1$ genes are not specific $P I$ regulators (Fig. $6 \mathrm{H}, \mathrm{I}$ ).

\section{Protein-protein interactions between PI and AP3}

There are several reasons to believe that PI and AP3 might act as partners in a heteromultimer. They act in the same places, times, and processes; and the homologs of $A P 3$ and $P I$ in snapdragons $(D E F$ and $G L O)$ have been reported to bind in vitro to MADS domain-binding sites, although only if the two proteins are translated together in the same in vitro translation reaction (Schwarz-Sommer et al. 1992; Tröbner et al. 1992). To see if PI and AP3 might act as a heteromultimer, we examined whether PI and AP3 proteins bind to each other in solution. A gene for a modified PI protein was constructed from a $P I$ cDNA clone: At the carboxyl terminus a synthetic oligonucleotide coding for an amino acid octamer (FLAG) was added, which is an epitope for commercially available monoclonal antibodies (anti-FLAG; see Materials and methods). RNA transcribed in vitro from this gene was translated in vitro to provide a source of epitopetagged PI. AP3 RNA was then produced by in vitro transcription from an $A P 3$ cDNA construct, and this was translated in vitro in the presence of $\left[{ }^{35} \mathrm{~S}\right]$ methionine to provide radioactively labeled AP3 protein. After mixing unlabeled but epitope-tagged PI with radioactively labeled AP3 protein, anti-FLAG antibody was used to precipitate the PI protein. The resulting immunoprecipitate was analyzed by SDS-PAGE (Fig. 7). Labeled AP3 was coprecipitated with the epitope-tagged PI protein, indicating that the two proteins associate in vitro.

Additional experiments were performed to determine whether the $\mathrm{K}$ domain, which by analogy to the similar region of keratin has been proposed to be involved in protein-protein interactions among plant MADS box proteins (Ma et al. 1991; Pnueli et al. 1991), or the MADS domain, is required for this interaction. An epitopetagged PI protein with part of the $\mathrm{K}$ box deleted (the part coding for amino acids 105-134) was used in experiments similar to the ones described above, and labeled AP3 was coprecipitated, though less efficiently than when full-length PI protein is used. Deletion of the MADS box from the epitope-tagged PI protein virtually eliminated the PI-AP3 interaction (Fig. 7). 

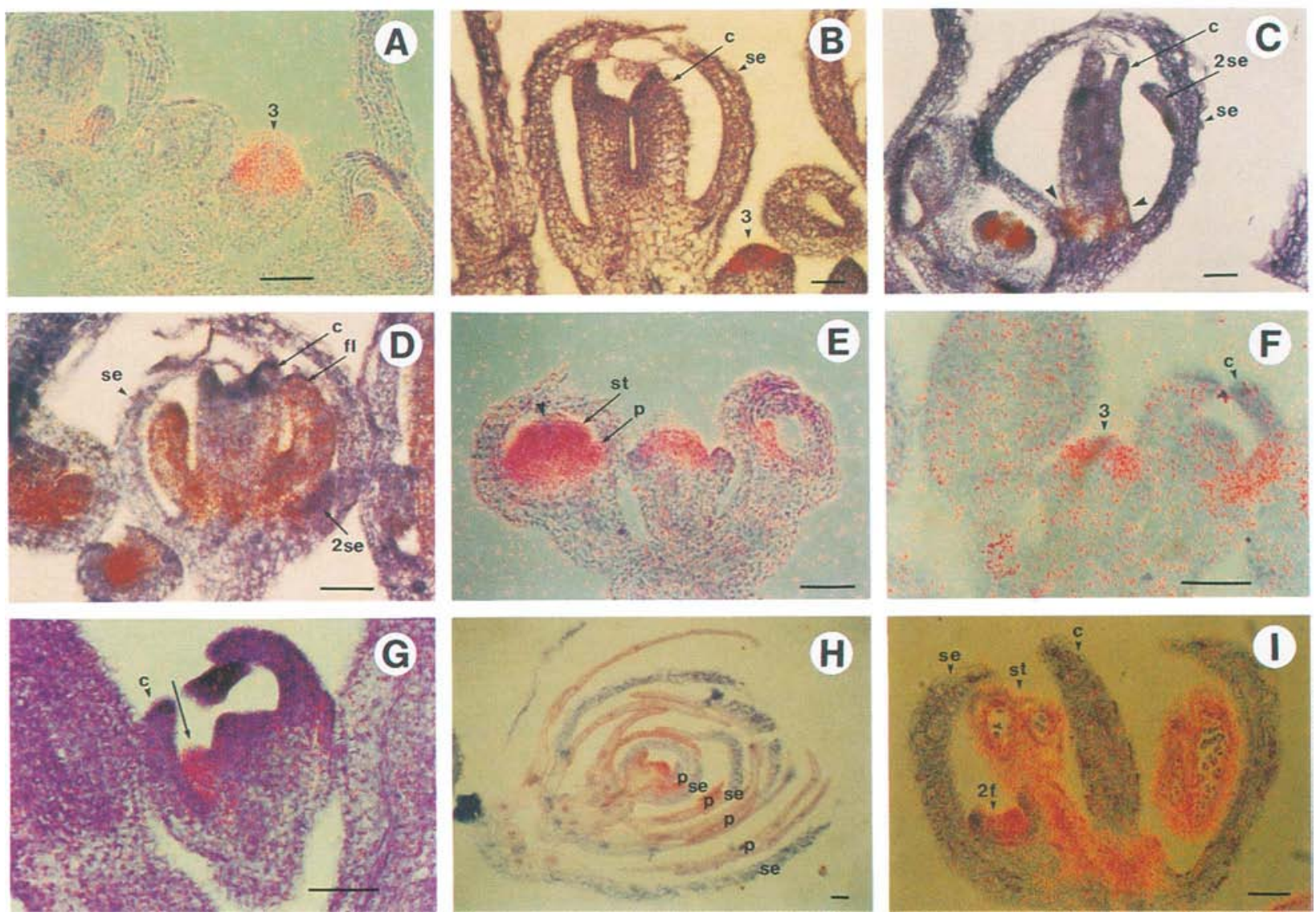

Figure 6. Expression of $P I$ RNA in mutant plants. The distribution of $P I$ transcripts in sections of various mutant flowers, as revealed by in situ hybridization with a labeled antisense PI probe. Exposure times are the same as those in Fig. 3 . Sepals (se), petals $\{\mathrm{p}$ ), stamens (st), and carpels $(\mathrm{c})$ are labeled. Bars, $50 \mu \mathrm{m}$. (A) ap3-3, a severe allele of ap3. In the stage 3 flower (indicated by the labeled arrowhead) $P I$ begins to express as in a wild-type flower, but the expression level begins to reduce at stage 5 , and by approximately stage 7 (to the right of the stage 3 floral bud) it is at a background level, except perhaps in the developing whorl 2 sepals, where it is approaching background level. Later stage buds are to the left of the stage 3 bud. $(B)$ pi-1, the most severe allele of pi. As in an ap3-3 flower, PI expresses normally in stages 3 and 4 , but after this, the level of PI RNA is reduced to an undetectable level. The middle flower is approximately stage 9, and there is no signal in the second whorl (no organ is seen in this section) or the third whorl region (occupied by developing carpels). (C) pi-2, which gives an intermediate phenotype among three pi mutant alleles, also shows normal PI expression during stages 3 and 4 . In approximately stage 10, Pl RNA is seen only in the base of the gynoecium forming in the third whorl region (arrowheads). In this flower, second whorl sepals (2se) develop, but signal is not observed in them at this late stage of development. (D) pi-3, the weakest pi mutant allele. The PI RNA expression pattern is similar to that seen in wild-type flowers, though sepals develop in the second whorl (2se) and filamentous carpels (fl) develop in the third whorl. (E) In the superman-1 mutant, early $P I$ expression seems much like that in wild type (stages 3 and 4 , as in the central stage 3/4 flower of this panel). In later stage flowers, PI RNA is seen much more centrally than in wild type, though in the center of each flower there is a small region without PI signal (arrowhead). Arrows labeled $\mathrm{p}$ and st represent developing petal and stamen, respectively. $(F, G)$ ap $2-8$, a strong allele of ap2. At stage $3(F), P I$ is expressed at a lower level than in a wild-type flower but in a normal domain. Second and third whorl organs are usually absent in ap2-8 flowers. On occasion, a staminoid organ will develop in this region; when it does, PI is expressed in it (arrow in G). When the first whorl carpels ( $c$ in $F$ and $G$ ) develop, $P I$ RNA is generally absent from them, as in $G$. Infrequently $P I$ is expressed at the base of developing first whorl organs, as in the flower on the right in $F$. $(H)$ An ag-1 flower has multiple repeats of $(s e p a l s$, petals, petals $\left.\right|_{n}$. PI RNA is clearly present in all petals (which arise in the second and third whorls) and in the same region of the floral meristem in which it is found in wild type. $\{I\}$ ap1-1, a strong loss-of-function allele of AP1. Second whorl organs are missing in these mutants, so the region of the second whorl cannot be identified (if it is there at all). Strong PI expression is observed in the stamens in primary and secondary $(2 \mathrm{f})$ flowers.

\section{Discussion}

The sequence of $P I$ shows it to be a member of the MADS box family of proteins, which includes the other Arabidopsis organ identity genes $A G, A P 3$, and $A P 1$, the snapdragon organ identity genes $D E F, G L O$, and
SQUAMOSA, and additional genes active in flower development in these and other plant species (SchwarzSommer et al. 1990; Ma et al. 1991; Pnueli et al. 1991; Angenent et al. 1992; van der Krol et al. 1993). The MADS box family also includes transcription factor proteins from animals [serum response factor or CArG-bind- 


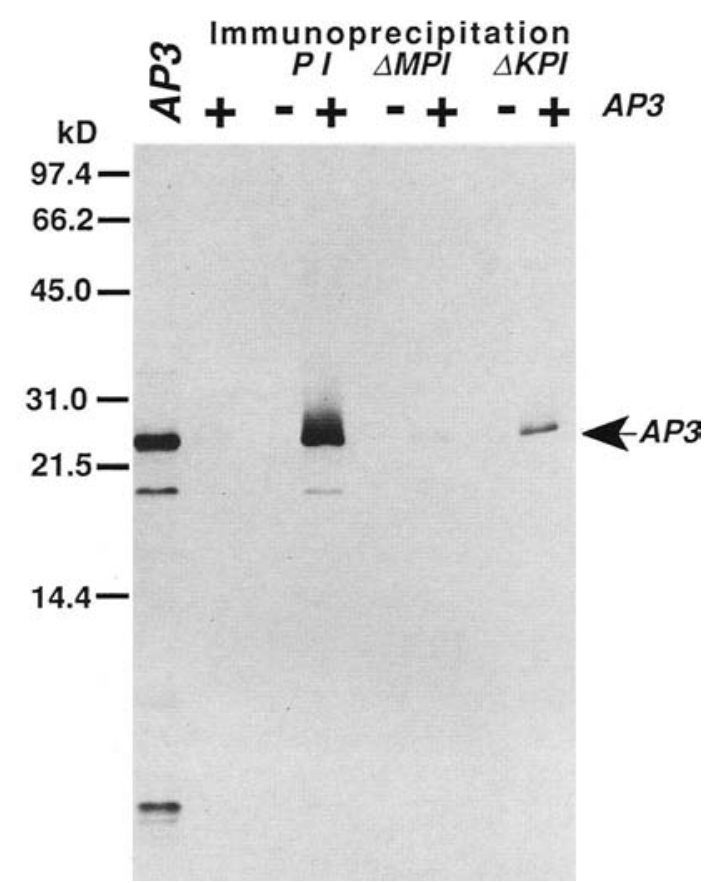

Figure 7. Coimmunoprecipitation of PI and AP3 proteins. A fluorograph of a polyacrylamide gel containing immunoprecipitated proteins. The arrow indicates the position of the fulllength AP3 protein. ${ }^{35} \mathrm{~S}$-Labeled AP3 protein was run in the lane marked AP3. The two minor bands in this lane are consistent with the expected sizes of products translated from internal methionines. The adjacent lane contains labeled AP3 protein immunoprecipitated without addition of epitope-tagged PI protein, to show the background of nonspecific precipitation of AP3 by the antibody. The following lanes contain epitopetagged PI (PI), tagged PI without the MADS box ( $\triangle \mathrm{MPI})$, and tagged PI with a partial deletion of the K-box $(\triangle \mathrm{KPI})$, which were mixed $|+|$ or not $|-|$ with radiolabeled AP3 protein and immunoprecipitated with anti-FLAG antibody.

ing factor (Norman et al. 1988; Boxer et al. 1989)]; myocyte-specific enhancer factor 2 (Yu et al. 1992), and fungi [MCMl or GRM/PRTF (Jarvis et al. 1989; Passmore et al. 1989|l, as well as genes of unknown function from both of these kingdoms (Dubois et al. 1987; Pollock and Treisman 1991). These findings imply that $P I$ is likely to encode a DNA-binding transcriptional regulator, which is in accord with its known developmental functions. The identities of the immediate downstream genes are unknown, though as discussed below, PI regulates both its own expression and that of the $A P 3$ gene. It is not yet known whether these activities are mediated directly. Because the absence of PI function influences the number and pattern of cells in floral organs and the differentiated phenotypes of these cells, the downstream genes must regulate pattern and number of cell divisions as well as differentiation of specific cell types.

In situ hybridization experiments have revealed that PI RNA accumulates in the second, third, and fourth whorls of developing flowers, starting by stage 3 of flower development, which occurs prior to the first ap- pearance of the primordia of petals and stamens. This initial pattern of expression does not coincide with the domain of the pi mutant phenotype, which is in the second and third whorls. It also does not coincide with the initial expression pattern of $A P 3$, the mutant phenotype of which is nearly identical with that of $p i$. Thus, fourth whorl expression does not seem to correlate with any organ identity activity. This early expression pattern does demonstrate that despite their similar activities and apparent action as partners, the genes $A P 3$ and $P I$ are controlled, at least in part, by different upstream regulatory factors. This implies a greater complexity to the earliest events in the specification of floral organ identity than has been realized so far.

After stage 4, the pattern of $P I$ expression largely coincides with that of $A P 3$ : $P I$ is no longer detected in whorl 4. This is apparently attributable to the absence of AP3 expression. Evidence for this is both that eliminating $A P 3$ activity from all whorls causes PI RNA to disappear from all whorls, as it does normally only in whorl 4, and that when $A P 3$ is ectopically expressed in the fourth whorl of developing flowers by attaching the AP3 gene to a foreign promoter, $P I$ remains active in the fourth whorl and allows stamens to form there (Jack et al. 1994|. Because $P I$ is also a maintenance factor for $A P 3$, at least in the third whorl (Jack et al. 1992), AP3 and $P I$ clearly form a positive regulatory circuit in which the activity of each is necessary for maintaining RNA accumulation from both.

The initial expression pattern of $P I$ raises the question of the mechanism by which $P I$ land the other organ identity genes) is activated in its initial expression domain. This is a central question in understanding organ specification in flowers, because both genetic and molecular experiments have shown that the differentiation of appropriate organ types in appropriate positions depends on the pattern of RNA accumulation from organ identity genes. The only gene whose activity is known to be necessary for initial expression of $P I$ is $L E A F Y$ ( $L F Y$; Weigel and Meyerowitz 1993). LFY acts along with $A P 1$ and $A P 2$ in the initial induction of the floral developmental pathway (Bowman et al. 1993). In situ hybridizations in which PI probes were used to locate the PI RNA in developing flowers of several additional mutant genotypes have shown that the pattern of expression of $P I$ depends in different ways on activity of the $P I$ gene itself, of the $A P 3$ gene, and of the SUPERMAN and AP2 genes. None of these genes is necessary for the initial expression of $P I$, however, indicating that other activities are responsible for initiating $P I$ expression and eliminating the possibility that $A P 3$ is required as an initial $P I$ activator. $S U$ $P E R M A N$ regulates $P I$ expression similarly to the way it regulates $A P 3$ expression: In the later stages of flower development in sup mutants, both $A P 3$ and PI RNAs are expressed much closer to the center of the flower than in the wild type, resulting in the development of extra stamens and, at the same time, a reduction or elimination of the region of the flower that develops into carpels. $S U P$ is thus formally a negative regulator of $P I$ in the region of flowers that in the wild type will give rise to 
the ovary. Although the activity of the SUP gene (possibly acting directly as a negative regulator of $A P 3$ and on $P I$ only indirectly) explains the absence of PI RNA in the center of wild-type flowers, we still do not know why $P I$ RNA is not present in the first floral whorl. This could be attributable to an absence of PI induction in this whorl or to the action of an as-yet-undiscovered negative regulator of PI RNA accumulation that acts in the first whorl.

$A P 2$ is also a regulator of PI RNA accumulation: A strong ap2 mutation reduces early, and generally eliminates late, RNA accumulation from the PI gene. There are two reasonable models for this interaction: Either $A P 2$ is one of the early-acting genes that induces $P I$ expression (like $L F Y$ ) or PI RNA is not found in developing ap2 flowers because the cells that would ordinarily comprise the second and third whorls are absent, or nearly so, in strong ap2 mutants. That the second of these possibilities may account for the absence of PI RNA in laterstage ap2 flowers is indicated by the fact that PI RNA is found in the rare second or third whorl staminoid organs that occasionally develop in ap2-8 flowers. $P I$ is therefore expressed in late-stage ap 2 mutant flowers, but this expression is only seen when second or third whorl cells divide to form organs.

Because many of the phenotypic and gene-regulatory effects of pi mutations are identical to those of ap3 mutations, it seems possible that AP3 and PI may act together as a heteromultimer. This possibility was tested by epitope tagging of a PI protein and showing that AP3 protein coprecipitates with PI in the presence of anti-tag antibodies. This coprecipitation is almost eliminated by deletion of the MADS box region of the PI protein and is reduced by deletion of part of the $\mathrm{K}$ box. This shows that AP3 and PI can form a heteromultimer in solution and indicates that the formation of the multimer may require the MADS domain and that it may be facilitated by the $\mathrm{K}$ domain. It is possible that the deletions affect protein folding, however, and that the MADS and $\mathrm{K}$ domains are not directly involved in the AP3-PI proteinprotein interaction.

As detailed below, $P I$ and the GLO gene of snapdragons are orthologs, as are AP3 and DEF (Jack et al. 1992). A different type of binding studies has been performed with the two snapdragon genes, in which in vitro cotranslation of the two proteins is necessary for them to bind to the MADS domain-binding site in the yeast STE6 promoter (CArG box; Schwarz-Sommer et al. 1992), and for binding to other CArG boxes, as well (Tröbner et al. 1992). These studies assay DNA binding by use of gel mobility retardation methods, whereas our studies assay protein-protein interactions between PI and AP3 directly, without requiring that they bind to specific DNA sequences. The results differ in detail because the snapdragon proteins need to be cotranslated to bind together to DNA, whereas in our studies heteromultimers form upon mixing of the proteins, without any need for their cotranslation. Nonetheless, both sets of in vitro studies suggest that AP3/PI or the orthologous pair DEF/GLO act as heteromultimers in vivo.
$P I$ is the ortholog of the Antirrhinum gene GLO (Tröbner et al. 1992), much as AP3 is the ortholog of the Antirrhinum gene $D E F$ (Jack et al. 1992). This is indicated by the similarity of their derived amino acid sequences. Although all four putative proteins (AP3, PI, DEF, and GLO) are related through their 57-amino-acid amino-terminal MADS box sequences, the pairs PI-GLO and AP3-DEF are related much more closely than the other possible pairs and are related through the entire length of the protein, including the carboxy-terminal region. These results clearly show that las long as the picture has not been confounded by gene conversion, and there is no indication of this) the pairs PI/GLO and AP3/DEF are orthologous, and the ancestral gene of each pair was present in the last common ancestor of $A$. thaliana and A. maius. These two species are in different subclasses of dicots (Cronquist 1981) and are thought to have been diverging since the Cretaceous, when the major radiations of flowering plants took place (Stewart and Rothwell 1993). The mechanisms served by these genes would thus seem to be similar in most or all flowering plants. Despite this, recent work on the apparent orthologs of AP3 and PI in Petunia (FBP1, pMADS1, and $p M A D S 2)$ has shown that whereas the activity of these genes in Petunia appears to be similar to that in Arabidopsis and Antirrhinum, in that together, they specify petals and stamens, the number and regulation of the genes may be different (Angenent et al. 1992, 1993; Kush et al. 1993; van der Krol et al. 1993). It therefore remains to be seen which aspects of $B$ gene function and regulation are fundamental and which have changed during the evolution of flowering plants.

\section{Materials and methods}

\section{Amplification of GLO cDNA}

Total RNA was extracted from A. majus flowers (collected on the Caltech campus) as described (Crawford et al. 1986), and poly $(\mathrm{A})^{+}$RNA was purified by use of PolyATtract system (Promega). Poly(A) ${ }^{+}$RNA $(3 \mu \mathrm{g}$ ) was used to synthesize doublestranded cDNA with a RiboClone cDNA synthesis system (Promega). This cDNA was amplified by PCR with degenerate oligonucleotides derived from the amino acid sequence of $G L O$. The primer sequences used for amplifying $G L O$ were $\mathrm{Kl}-5^{\prime}$ [TC]TCCATNAC[GA]TT[GA]TC[GA]TTCAT-3'-and K115'-GA[GA]AT[ATC]AA[GA][AC]GNAT[ATC]GA[GA]AA[CT]TC- $3^{\prime}$. Mixed nucleotides are shown in brackets, with $N$ indicating a GATC mixture. One major and several minor amplified bands were seen by agarose gel electrophoresis. The major band was cut out and sequenced directly. The deduced amino acid sequence of this DNA corresponds to that of GLO. This PCRamplified GLO DNA was labeled by nick translation with $\left[\alpha-{ }^{32} \mathrm{P}\right] \mathrm{dCTP}$ and used as a probe for library screening.

\section{Cloning of PI}

An Arabidopsis flower cDNA library (Weigel et al. 1992), constructed using floral RNA from the Landsberg erecta (L-er) wild type and in the Lambda ZAP II Vector (Stratagene), was screened with PCR-amplified GLO cDNA under reduced stringency conditions (hybridization, $50^{\circ} \mathrm{C}, 4 \times \mathrm{SSPE}_{\text {; }}$ wash, $55^{\circ} \mathrm{C}, 2 \times \mathrm{SSPE}$ ). Eight independent plaques out of $2 \times 10^{4}$ plaques screened were 
hybridized strongly with the probe. These eight positives were isolated and in vivo excision of pBluescript and the cDNA insertion sequences was performed according to the manufacturer's instructions. The cDNA insert was then sequenced with a Sequenase II kit (U.S. Biochemical). The insert sizes of these clones ranged from $\sim 500$ to $900 \mathrm{bp}$. All of the shorter inserts had truncated versions of the sequence in the longest one, which was designated cGH12.

In parallel, a cosmid library, made from $L$-er genomic DNA by use of the vector pCIT30 ( $\mathrm{Ma}$ et al. 1992), was screened under the same conditions as were used in the cDNA library screening. Four cosmid clones gave strong hybridization signals. Inserts of these isolated cosmids were tested for cross-hybridization but none of them hybridized with each other under high stringency conditions (hybridization, $65^{\circ} \mathrm{C}, 4 \times \mathrm{SSPE}$; wash, $65^{\circ} \mathrm{C}, 0.1 \times \mathrm{SSPE}$ ). One cosmid clone, $\mathrm{GH} 13$, hybridized to the cDNA clone (cGH12) at high stringency conditions.

Two XbaI fragments of GH13 (1.2 and $3.7 \mathrm{~kb}$ ) hybridize to the cDNA clone. These two fragments were ligated to the $X b a$ I site of pGEM- $7 \mathrm{Zf} \mid+1$, and a series of restriction endonuclease digestions were made and the resulting fragments subcloned, after which the subclones were sequenced as described above.

\section{RFLP mapping}

Plants from the L-er wild type, homozygous for pi-1, were crossed to wild-type plants of the Niederzenz (Nd-0) ecotype. $F_{1}$ plants were backcrossed to pi-1 homozygotes, and DNA was prepared from individual progeny of this cross. The DNA was analyzed by Southern blot hybridization for the segregation of known RFLP markers (Chang et al. 1988; Hauge et al. 1993). For cosmid GH13, 63 of 64 individuals that we examined scored identically to pi, indicating very close but not perfect linkage. Before it was used for DNA extraction, the plant numbered 102 had been scored as phenotypically $\mathrm{Pi}^{-}$. It scored as a Landsberg/ Niederzenz heterozygote in RFLP mapping when markers adjacent to PI on either side were used as probes, as well as heterozygous for the GH13 polymorphism. We conclude that this individual was scored incorrectly for the pi phenotype because molecular evidence shows both that the entire $P I$ region was heterozygous and that GH13 contains the PI gene.

\section{Direct sequencing of PCR products}

PCR-amplified products were separated by electrophoresis on $1 \%$ LMP agarose gels (BRL), and bands of expected sizes were excised. The excised fragments of the LMP agarose gel were melted at $65^{\circ} \mathrm{C}$, and $9 \mu \mathrm{l}$ of melted agarose was mixed with $1 \mu \mathrm{l}$ of $10 \mu \mathrm{M}$ sequence primer and $1.2 \mu \mathrm{l}$ of $5 \% \mathrm{NP}-40$. Immediately after boiling for $3 \mathrm{~min}$, this mixture was placed in a $37^{\circ} \mathrm{C}$ water bath, after which dideoxy sequencing was performed by use of a Sequenase II kit (U.S. Biochemicals) according to the manufacturer's instructions.

\section{Sequencing of pi mutant alleles}

The first strand of cDNA was synthesized from $2 \mu \mathrm{g}$ of poly $(\mathrm{A})^{+}$ RNA extracted from the flowers of $p i-1, p i-2$, and $p i-3$ homozygous mutant plants. Each of these PI mutations was induced by use of the mutagen EMS (ethylmethane sulfonate) in the genetic background L-er (Bowman et al. 1991). These cDNAs were amplified by PCR with primers that have the sequences of the $5^{\prime}$ and $3^{\prime}$ ends of the sequenced wild-type cDNA. Each PCR reaction with mutant cDNA produced the expected size of amplified DNA. We directly sequenced two independent PCR products for each mutant allele. To confirm the results of direct sequencing, amplified DNAs were cloned into pGEM-7Zf $\mid+1$ (Promega), and three independent clones of each mutant type were sequenced. The sequences of these clones correspond to the results obtained from direct sequencing.

\section{In situ hybridization}

To make the hybridization probe, we constructed pcPINX, which has an NcoI-XhoI fragment of PI cDNA la fragment not including the MADS box, to avoid cross-hybridization to other MADS box genes) inserted in the BamHI and XhoI sites of pGEM-7Zf $\mid+1$. To make an antisense probe, pcPINX was linearized by $\mathrm{BamHI}$, and in vitro transcription with T7 RNA polymerase was used to incorporate $\left[{ }^{35} \mathrm{~S}\right] \mathrm{UTP}$. Tissue fixation, hybridization, and washing conditions were carried out as described by Drews et al. (1991a). The thickness of the paraffin sections used was $8 \mu \mathrm{m}$ except for the alternate sections experiment (shown in Fig. 5), in which the sections used were $6 \mu \mathrm{m}$ thick. Slides were developed following 2- to 5-week exposures. As a control, a sense-orientation probe made from an identical template was used in identical experiments; no signal was seen in the controls.

\section{Immunoprecipitation}

To make the FLAG-tagged PI protein, pPIFLAG was constructed in pGEM-3Z (Promega). This plasmid includes a synthetic oligonucleotide that codes for the FLAG epitope, in place of the ClaI-Xhol region of the PI cDNA. This results in the addition of a peptide, DDADTKDDDDK, at the carboxy-terminal end of the PI protein. By NcoI digestion, p $\triangle$ MPIFLAG was made to produce MADS box-deleted PI protein that has the deletion from $M$ (at position 1) to $S$ (61). To delete the $\mathrm{K}$ box, pPIFLAG was digested with SacI and Tthl11I, and after removing the small fragment, the plasmid was recircularized by blunt-end ligation. p $\triangle K P I F L A G$ encodes a PI protein with L (105) through $\mathrm{K}$ (134) deleted, which removes 30 amino acids from the $\mathrm{K}$ box. The TNT-coupled reticulocyte lysate system (Promega) was used to make in vitro-translated proteins. To produce radioactively labeled AP3 protein, pF730 (Jack et al. 1992) was used as a template and $\left[{ }^{35} \mathrm{~S}\right]$ methionine was incorporated. After $1 \mathrm{hr}$ incubation at $30^{\circ} \mathrm{C}$, the in vitro translation solution was diluted with an equal volume of $2 \times$ buffer A $(40 \mathrm{~mm}$ HEPES-KOH at $\mathrm{pH}$ $7.9,0.4 \mathrm{~mm}$ EDTA, $20 \%$ glycerol, $200 \mathrm{~mm} \mathrm{KCl}, 2 \mathrm{~mm}$ DTT) to stop the translation reaction (Blanar and Rutter 1992). Each protein solution $(20 \mu \mathrm{l})$ was mixed and left at room temperature for $30 \mathrm{~min}$ to allow protein association. After this, $1 \mu \mathrm{g}$ of antiFLAG M2 monoclonal antibody (Kodak-IBI) and $10 \mu \mathrm{g}$ of protein A-Sepharose (Sigma) in ice-cold $500 \mu$ l of buffer B (buffer B contains $2.5 \mathrm{mM} \mathrm{MgCl}$ and $0.1 \% \mathrm{NP}-40$ in addition to buffer A) were added. After incubation on a rotating wheel at $4^{\circ} \mathrm{C}$ for 1 $\mathrm{hr}$ and centrifugation, the pellet was washed four times with ice-cold buffer $B$. The washed pellet was resuspended in $2 \times$ SDS sample buffer, and the proteins were analyzed by SDS-PAGE and fluorography using $\mathrm{EN}^{3} \mathrm{HANCE}$ (DuPont).

\section{Acknowledgments}

We thank the members of our laboratory for reading and suggesting changes to the manuscript, and S. Schwarz-Sommer for communicating the amino acid sequence of the GLOB gene prior to its publication. K.G. was a Human Frontier Science Program postdoctoral fellow. This work was funded by grant MCB-9204839 from the U.S. National Science Foundation.

The publication costs of this article were defrayed in part by 
payment of page charges. This article must therefore be hereby marked "advertisement" in accordance with 18 USC section 1734 solely to indicate this fact.

\section{Note added in proof}

The nucleotide sequence data described in this paper have been submitted to the GSDB, DDBI, EMBL, and NCBI data bases under accession number D30807.

\section{References}

Angenent, G.C., M. Busscher, J. Franken, J.N.M. Mol, and A.J. van Tunen. 1992. Differential expression of two MADS box genes in wild-type and mutant Petunia flowers. Plant Cell 74: 983-993.

Angenent, G.C., J. Franken, M. Busscher, L. Colombo, and A.J. van Tunen. 1993. Petal and stamen formation in petunia is regulated by the homeotic gene fbp1. Plant J. 4: 101-112.

Blanar, M.A. and W.J. Rutter. 1992. Interaction cloning: Identification of a helix-loop-helix zipper protein that interacts with c-Fos. Science 256: 1014-1018.

Bowman, J.L., D.R. Smyth, and E.M. Meyerowitz. 1989. Genes directing flower development in Arabidopsis. Plant Cell 1: 37-52.

Bowman, J.L., D.R. Smyth, and E.M. Meyerowitz. 1991. Genetic interactions among floral homeotic genes of Arabidopsis. Development 112: 1-20.

Bowman, J.L., H. Sakai, T. Jack, D. Weigel, U. Mayer, and E.M. Meyerowitz. 1992. SUPERMAN, a regulator of floral homeotic genes in Arabidopsis. Development 114: 599-615.

Bowman, J.L., J. Alvarez, D. Weigel, E.M. Meyerowitz, and D.R. Smyth. 1993. Control of flower development in Arabidopsis thaliana by APETALA1 and interacting genes. Development 119: 721-743.

Boxer, L.M., R. Prywes, R.G. Roeder, and L. Kedes. 1989. The sarcomeric action CArG-binding factor is indistinguishable from the c-fos serum response factor. Mol. Cell. Biol. 9: 515522.

Chang, C., J.L. Bowman, A.W. DeJohn, E.S. Lander, and E.M. Meyerowitz. 1988. Restriction fragment length polymorphism linkage map for Arabidopsis thaliana. Proc. Natl. Acad. Sci. 85: 6856-6860.

Coen, E.S. and E.M. Meyerowitz. 1991. The war of the whorls: Genetic interactions controlling flower development. $\mathrm{Na}$ ture 353: 31-37.

Crawford, N.M., W.H. Campbell, and R.H. Davis. 1986. Nitrate reductase from squash: cDNA cloning and nitrate regulation. Proc. Nat. Acad. Sci. 83: 8073-8076.

Cronquist, A. 1981. An integrated system of classification of flowering plants. Columbia University Press, New York.

Drews, G.N., J.L. Bowman, and E.M. Meyerowitz. 1991a. Negative regulation of the Arabidopsis homeotic gene $A G A$ MOUS by the APETALA2 product. Cell 65: 991-1002.

Drews, G.N., D. Weigel, and E.M. Meyerowitz. 1991b. Floral patterning. Curr. Opin. Genet. Dev. 1: 174-178.

Dubois, E., J. Bercy, and F. Messenguy. 1987. Characterization of 2 genes, ARGRI and ARGRIII required for specific regulation of arginine metabolism in yeast. Mol. \& Gen. Genet. 207: 142-148.

Fryxell, K.J. and E.M. Meyerowitz. 1991. The evolution of rhodopsins and neurotransmitter receptors. J. Mol. Evol. 33: 367-378,

Gustafson-Brown C., B. Savidge, and M.F. Yanofsky. 1994. Regulation of the Arabidopsis floral homeotic gene APETALA1. Cell 76: 131-143.

Hansen, G., J.J. Estruch, H. Sommer, and A. Spena. 1993. NT-
GLO: A tobacco homolog of the GLOBOSA floral homeotic gene of Antirrhinum majus: cDNA sequence and expression pattern. Mol. \& Gen. Genet. 239: 310-312.

Hauge, B.M., S.M. Hanley, S. Cartinhour, J.M. Cherry, H.M. Goodman, M. Koornneef, P. Stam, C. Chang, S. Kempin, L. Medrano, and E.M. Meyerowitz. 1993. An integrated genetic/RFLP map of the Arabidopsis thaliana genome. Plant I. 3: 745-754.

Hill, J.P. and E.M. Lord. 1989. Floral development in Arabidopsis thaliana: Comparison of the wildtype and the homeotic pistillata mutant. Can. J. Bot. 67: 2922-2936.

Irish, V.F. and I.M. Sussex. 1990. Function of the apetala-1 gene during Arabidopsis floral development. Plant Cell 2: 741753.

Jack, T., L.L. Brockman, and E.M. Meyerowitz. 1992. The homeotic gene APETALA3 of Arabidopsis thaliana encodes a MADS box and is expressed in petals and stamens. Cell 68: 683-697.

Jack T., G.L. Fox, and E.M. Meyerowitz. 1994. Arabidopsis homeotic gene APETALA3 ectopic expression: Transcriptional and posttranscriptional regulation determine floral organ identity. Cell 76: 703-716.

Jarvis, E.E., K.L. Clark, and G.F. Sprague Jr. 1989. The yeast transcription factor PRTF, a homolog of the mammalian serum response factor, is encoded by the MCM1 gene. Genes \& Dev. 3: 936-945.

Kunst, L., J.E. Klenz, J. Martinez-Zapater, and G.W. Haughn. 1989. AP2 gene determines the identity of perianth organs in flowers of Arabidopsis thaliana. Plant Cell 1: 1195-1208.

Kush, A., A. Brunelle, D. Shevell, and N.-H. Chua. 1993. The cDNA sequence of 2 MADS box proteins in petunia. Plant Physiol. 102: 1051-1052.

Ma, H., M.F. Yanofsky, and E.M. Meyerowitz. 1991. AGL1AGL6, an Arabidopsis gene family with similarity to floral homeotic and transcription factor genes. Genes \& Dev. 5: 484-495.

Ma, H., M.F. Yanofsky, H.J. Klee, J.L. Bowman, and E.M. Meyerowitz. 1992. Vectors for plant transformation and cosmid libraries. Gene 117: 161-167.

Mandel, M.A., C. Gustafson-Brown, B. Savidge, and M.F. Yanofsky. 1992. Molecular characterization of the Arabidopsis floral homeotic gene APETALA1. Nature 360: 273-277.

Meyerowitz, E.M., D.R. Smyth, and J.L. Bowman. 1989. Abnormal flowers and pattern formation in floral development. Development 106: 209-217.

Meyerowitz, E.M., J.L. Bowman, L.L. Brockman, G.N. Drews, T. Jack, L.E. Sieburth, and D. Weigel. 1991. A genetic and molecular model for flower development in Arabidopsis thaliana. Development (Suppl. 1) 112: 157-168.

Nam, H.-G., J. Giraudat, B. den Boer, F. Moonan, W.D.B. Loos, B.M. Hauge, and H.M. Goodman. 1989. Restriction fragment length polymorphism linkage map of Arabidopsis thaliana. Plant Cell 1: 699-705.

Norman, C., M. Runswick, R. Pollock, and R. Treisman. 1988. Isolation and properties of cDNA clones encoding SRF, a transcription factor that binds to the $\mathrm{c}$-fos serum response element. Cell 55: 989-1003.

Okamuro, J.K., B.G.W. Den Boer, and K.D. Jofuku. 1993. Regulation of Arabidopsis flower development. Plant Cell 5: 1183-1193.

Passmore, S., G.T. Maine, R. Elble, C. Christ, and B.-K. Tye. 1988. Saccharomyces cerevisiae protein involved in plasmid maintenance is necessary for mating of mat-alpha cells. $J$. Mol. Biol. 204: 593-606.

Passmore, S., R. Elble, and B.-K. Tye. 1989. A protein involved in minichromosome maintenance in yeast binds a transcrip- 
tional enhancer conserved in eukaryotes. Genes \& Dev. 3: 921-935.

Pnueli, L., M. Abu-Abeid, D. Zamir, W. Nacken, Z. SchwarzSommer, and E. Lifschitz. 1991. The MADS box gene family in tomato: Temporal expression during floral development, conserved secondary structure and homology with homeotic genes from Antirrhinum and Arabidopsis. Plant I. 1: 255266.

Pollock, R. and R. Treisman. 1991. Human SRF-related proteins-DNA-binding and potential regulatory targets. Genes \& Dev. 5: 2327-2341.

Schultz, E.A. and G.W. Haughn. 1991. Leafy, a homeotic gene that regulates inflorescence development in Arabidopsis. plant Cell 3: 771-781.

Schwarz-Sommer, Z., P. Huijser, W. Nacken, H. Saedler, and H. Sommer. 1990. Genetic control of flower development: Homeotic genes in Antirrhinum maius. Science 250: 931-936.

Schwarz-Sommer, Z., I. Hue, P. Huijser, P.J. Flor, R. Hansen, F. Tetens, W.-E. Lönnig, H. Saedler, and H. Sommer. 1992. Characterization of the Antirrhinum floral homeotic MADS-box gene deficiens: Evidence for DNA binding and autoregulation of its persistent expression throughout flower development. EMBO I. 11: 251-263.

Smyth, D.R., J.L. Bowman, and E.M. Meyerowitz. 1990. Early flower development in Arabidopsis. Plant Cell 2: 755-767.

Sommer, H., J.P. Beltrán, P. Huijser, H. Pape, W.E. Lönnig, H. Saedler, and Z. Schwarz-Sommer. 1990. Deficiens, a homeotic gene involved in the control of flower morphogenesis in Antirrhinum majus: The protein shows homology to transcription factors. EMBO J. 9: 605-613.

Stewart, W.N. and G.W. Rothwell. 1993. Paleobotany and the evolution of plants. Cambridge University Press, Cambridge, UK.

Tröbner, L. Ramirez, P. Motte, I. Hue, P. Huijser, W. Lönnig, H. Saedler, H. Sommer, and Z. Schwarz-Sommer. 1992. Globosa-A homeotic gene which interacts with deficiens in the control of Antirrhinum floral organogenesis. EMBO I. 11: 4693-4704.

van der Krol, A.R., A. Brunelle, S. Tsuchimoto, and N.-H. Chua. 1993. Functional analysis of petunia floral homeotic MADS box gene pMADS1. Genes \& Dev. 7: 1214-1228.

Weigel, D. and E.M. Meyerowitz. 1993. Activation of floral homeotic genes in Arabidopsis. Science 261: 1723-1726.

Weigel, D., J. Alvarez, D.R. Smyth, M.F. Yanofsky, and E.M. Meyerowitz. 1992. LEAFY controls floral meristem identity in Arabidopsis. Cell 69: 843-859.

Yanofsky, M.F., H. Ma, J.L. Bowman, G.N. Drews, K.A. Feldmann, and E.M. Meyerowitz. 1990. The protein encoded by the Arabidopsis homeotic gene agamous resembles transcription factors. Nature 346: 35-39.

Yu, Y.-T., R.E. Breitbart, L.B. Smoot, Y. Lee, V. Mahdavi, and B. Nadal-Ginard. 1992. Human myocyte-specific enhancer factor-II comprises a group of tissue-restricted MADS box transcription factors. Genes \& Dev. 6: 1783-1798. 


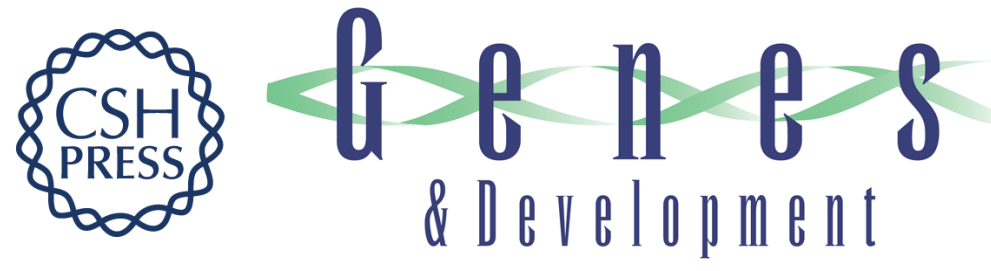

\section{Function and regulation of the Arabidopsis floral homeotic gene PISTILLATA.}

K Goto and E M Meyerowitz

Genes Dev. 1994, 8:

Access the most recent version at doi:10.1101/gad.8.13.1548

References This article cites 48 articles, 23 of which can be accessed free at:

http://genesdev.cshlp.org/content/8/13/1548.full.html\#ref-list-1

License

Email Alerting

Service

Receive free email alerts when new articles cite this article - sign up in the box at the top right corner of the article or click here.

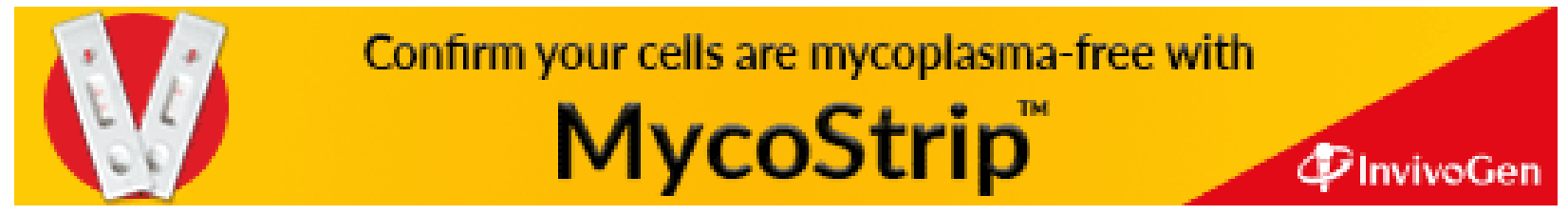

